
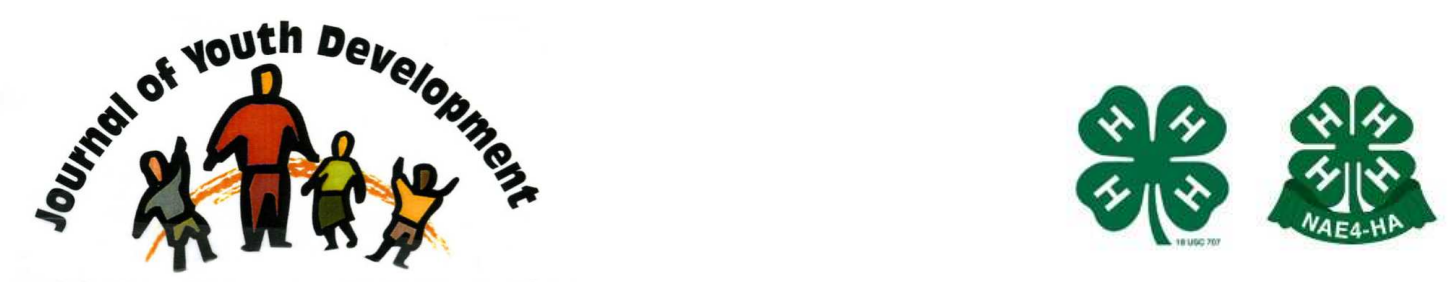

Bridging Research \& Practice

\title{
Television and the Internet: The Role Digital Technologies Play in Adolescents' Audio-Visual Media Consumption. Young Television Audiences in Catalonia (Spain)
}

\author{
Meritxell Roca \\ Interdisciplinary Internet Institute (IN3) \\ Universitat Oberta de Catalunya \\ New York, NY \\ mrocasa@uoc.edu \\ Daniel Aranda \\ Interdisciplinary Internet Institute (IN3) \\ Universitat Oberta de Catalunya \\ Barcelona, Spain \\ darandaj@uoc.edu \\ Jordi Sánchez-Navarro \\ Interdisciplinary Internet Institute (IN3) \\ Universitat Oberta de Catalunya \\ Barcelona, Spain \\ jsancheznav@uoc.edu
}




\title{
JOURNAL OF YOUTH DEVELOPMENT \\ bridging research and practice

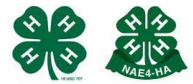

Volume 9, Number 1, Special Edition 2014

Article 140901FA005

\section{Television and the Internet: The Role Digital Technologies Play in Adolescents' Audio-Visual Media Consumption. Young Television Audiences in Catalonia (Spain)}

\author{
Meritxell Roca, Daniel Aranda and Jordi Sánchez-Navarro \\ Universitat Oberta de Catalunya
}

\begin{abstract}
The aim of this reported study was to investigate adolescents TV consumption habits and perceptions. Although there appears to be no general consensus on how the Internet affects TV consumption by teenagers, and data vary depending on the country, according to our study, Spanish adolescents perceive television as a habit "of the past" and find the computer a device more suited to their recreational and audio-visual consumption needs. The data obtained from eight focus groups of teenagers aged between 12 and 18 and an online survey sent to their parents show that watching TV is an activity usually linked to the home's communal spaces. On the contrary, online audio-visual consumption (understood as a wider term not limited to just TV shows) is perceived by adolescents as a more convenient activity as it adapts to their own schedules and needs.
\end{abstract}

\section{Introduction}

Technological changes have traditionally been a driving force behind the evolution of audiovisual media; the Internet is no exception. However, apart from popularising services such as television (content made available to anyone with access to the Internet), the World Wide Web has ignited an attitudinal shift, a reformulation of consumers' routines. The Internet has enabled personalised à la carte content consumption: we can nowadays watch whatever we choose, not only wherever we want but also whenever we prefer.

There is no reason to believe that the television industry would remain unaffected by this change in consumer habits. According to the focus group discussions we conducted, statistics and previously published researches, all point in the same direction: television consumption, at least as we understood it until a few years ago, is over. 
Information and Communication Technologies (ICT), particularly the Internet, have led to a new scenario in media consumption habits and consumers' behaviour to which both the Entertainment industry and the Advertising industry are trying to respond. As a consequence, media business models are being transformed in order to be coherent with this new environment (sometimes referred to as Entertainment 2.0). The classic communication paradigm based on a broadcaster (the media) that created content that would subsequently be broadcast (distributed) to a vast and impersonal audience is currently subject to revision. Although there is a television model that is still based on these parameters (and we will later see that this model is proven to be very successful amongst Catalan and Spanish audiences), the Internet has also made it possible for anonymous people to distribute content, which sometimes may even be more popular than this created by traditional media corporations. If forced to choose between television and the Internet, $65 \%$ of young Spaniards would choose the Web. In addition, $48 \%$ of Spanish Internet users consume streaming audio-visual content an average of six and a half hours a week (Mediascope Europe, 2010), so it can be stated that conventional television is facing a powerful new rival.

\section{Purpose and objectives}

The purpose of this study was to examine how teenagers consume media, which are their preferences and their routines. The study was guided by the following objectives:

a) Describe which are teenagers' audio-visual consumption habits and practices.

b) Determine which role technology plays in addressing these demands.

c) Analyse how the Internet has changed the way families consume media and television in particular? Do families still gather together to watch a TV program?

d) Characterize adolescents' online practices regarding their social, cultural and psychological needs.

\section{Research methodology}

Since we wanted to engage teenagers in discussion about their audio-visual consumption habits and practices, the data for this study come from focus groups (Creswell, 1998; Fern, 2001; Lindlof \& Taylor, 2002) and it is analyzed from a grounded theory perspective (Charmaz, 2005; Glaser \& Strauss, 1967). However, that approach is complemented with an online survey sent to parents. This paper presents the results from both sources, being aware that the sample is not representative. However, it provides the reader with data and information that will give comprehensive understanding of the changes in teenagers' media consumption and their consequences on family routines.

\section{Focus groups: subjects, site selection and process}

Eight focus groups were conducted with a total of 48 teenagers. Initial contacts were made with the Principals of four schools after the selection of the sample of secondary education centres was made. It was a random selection; the only condition was that each of Catalonia's four provinces had to be represented.

Two groups were held at each school, one with ESO (Educació Secundària Obligatòria, Compulsory Secondary Education) students aged between 12 and 16 and the other with Batxillerat (Baccalaureate) students, aged 17 and 18. The focus groups took place from January to March 2012 and each consisted of six students of both sexes ( 3 boys and 3 girls), chosen by 
the Centre following research group guidelines that the groups should reflect the school's diversity in terms of cultural and socio-economic backgrounds.

The focus groups were, on average, one hour long. The three authors (and members of the research group) attended all of the sessions. One of them adopted a proactive role, leading the conversation by assuring all of the research questions were addressed throughout the discussion. A second member of the team adopted a secondary role, and merely brought to the table those topics or concerns that were on the conversation guide (Figure 1) but were not being discussed. The third member of the group, was in charge of recording the session.

Figure 1

Conversation guide used at the focus groups

EQUIPMENT: number of television sets, computers and cell phones per household. Room hosting the set, main users, favourite shows and identification of those which are watched by the whole family at the same time.

INTERNET - ACTIVITIES: practices and content watched online (computer, cell phones, other devices...); when and where the activity takes place.

INTERNET - CONTENT SHARING: which content, what platform, with whom.

LEISURE PREFERENCES: ask participants to rank the following activities according to their preferences: hanging out with friends, watching TV and surfing the Internet.

PARENTAL CONTROL (TV and Internet). Description and perceptions. PARENTS and TECHNOLOGY: different practices due to digital divide? Shared practices with computer and/or computer connected to the TV set.

VIDEOGAMES: individual/shared playing (parents, friends, brothers and sisters...). Online multiplayer games. Room hosting videogame practices at home.

CINEMA and other cultural activities that imply audio-visual consumption.

All focus-groups interactions were transcribed. Analysis followed a coding template that was developed based on major data themes. Out of the approximately 25 nodes, this article focuses on the technology and TV related ones and particularly on two aspects: digital recreation and adolescents' psychological needs; and, adolescents' perception of the Internet and TV. Readers interested in accessing the entire research project and findings may consider reading the research report, http://journals.uoc.edu/ojs/index.php/in3-working-paper-

series/article/view/n12-roca. (Please not the full text is available only in Catalan.)

Regarding quotation of certain fragments of the discussions, in order to ensure that participants remain anonymous, this paper identifies the participant only by mentioning sex, educational level and School's location. Note that all quotes have been translated from the original speech and may contain some grammatical errors.

\section{Online survey}

In addition to the focus groups, we carried out an online survey with parents from the Educational Centres that participated in the study. The survey was launched in February and a second invitation email to complete the questionnaire (reminder) was sent in March. The survey remained active for a month. 
No institutional invitation to complete it was sent from the Schools; AMPAs (parents' associations) emailed their affiliates a brief description of the study and encouraged parents to answer the questions. There were no incentives.

Survey data were analysed using SPSS. The population was of 1054 persons, and for our study we used a random sample of $n=257$ persons with a $95 \%$ confidence level (i.e., significance level $=0.05$ ).

\section{Findings}

\section{Digital recreation and adolescents' psychosocial needs}

Our focus groups and online survey show that television consumption is an activity driven by two different aspects: home's communal spaces and broadcasters' programming schedules. It is of particular interest that television consumption is influenced by the location of the TV sets. Accordingly, placement of television sets in communal spaces in the house is a measure that works well for parents who wish to monitor (and control) what contents are being watched. On the other hand, the fact that families depend on broadcasters' programming schedules is nothing noteworthy in Catalonia and in Spain where devices like DVRs are not popular. Currently only cable and dish TV offer that feature (iPlus from Canal +, and TiVo from Ono) in a context where, broadly speaking, large audiences prefer to watch free programming instead of pay per view. According to CMT (Comisión del Mercado de las Telecomunicaciones - National Telecommunications Market Commission), pay TV penetration rate in Spain was of 9.8 subscribers every 100 inhabitants in 2011. Not surprisingly, online audio-visual consumption is considered by adolescents as a convenient practice that better fits their social, cultural and psychological needs.

Media, and television in particular, play a decisive role in children and adolescents' everyday lives but they haven't replaced peer relationships (Boyd, 2008; Cobo, 2010; Ito, 2008, 2009, 2010; Jenkins, 2008; Prensky, 2001; Rheingold, 2002; Sánchez, \& Aranda, 2013; Tapscott, 1998; Valkenburg, \& Peter, 2011; Valkenburg, Sumter, \& Peter, 2011). Children usually prefer spending time with friends rather than watching a film on a TV set in the living-room or surfing the Web in their bedroom. Nevertheless, numerous studies have contributed to the understanding of how Internet usage provides a better fit for the needs of young people than other forms of media consumption. Of particular interest for this research are studies focusing on the relationship between digital recreation practices and activities and adolescence, and more specifically, how the Internet can be used to address teenagers' psychosocial needs.

According to Valkenburg, Sumter and Peter (2011), proper psychosocial development in adolescence depends to a large extent on the quality of the development of the following aspects: identity, privacy and sexuality. Adolescents must develop strong self-awareness and need to be sure of who they are and what they want to be. Developing a certain sense of privacy also matters, and they need to acquire skills that are important in order to start, manage and eventually end relationships. Moreover, they also need to develop their sexuality. In the end, adolescents must (a) become accustomed to the feelings associated with sexual desire, (b) establish and accept their sexual orientation and (c) learn how to build healthy, consensual and honest sexual relationships. To ensure proper development of these psychosocial aspects, adolescents need to learn how to present themselves to others (selfpresentation) and how to share intimate aspects with others (self-disclosure). Accordingly, other studies published by Boyd (2007), Ito (2010), and Valkenburg and Peter (2011), indicate 
that Social Networking Sites (SNSs) offer adolescents a space where they can work on their identity, status and understanding of social rules.

If we take a look at the online activities carried out by children and teenagers, and bearing in mind the nature of this study, studies such as Generación Interactiva (published by Fundación Telefónica) provide meaningful insight on which are the top main activities among Spanish youth (figure 2). Not surprisingly, MSN (Microsoft Messenger) and SNSs are two of the top three activities. Although the study does not include a specific variable regarding audio-visual consumption, "content sharing" and "downloading films and music," which imply some sort of audio-visual interaction, also account for high rates.

Figure 2

Internet use by children and teenagers ( 10 to 18 years old) in 2009

Source: Generación Interactiva, Fundación Telefónica

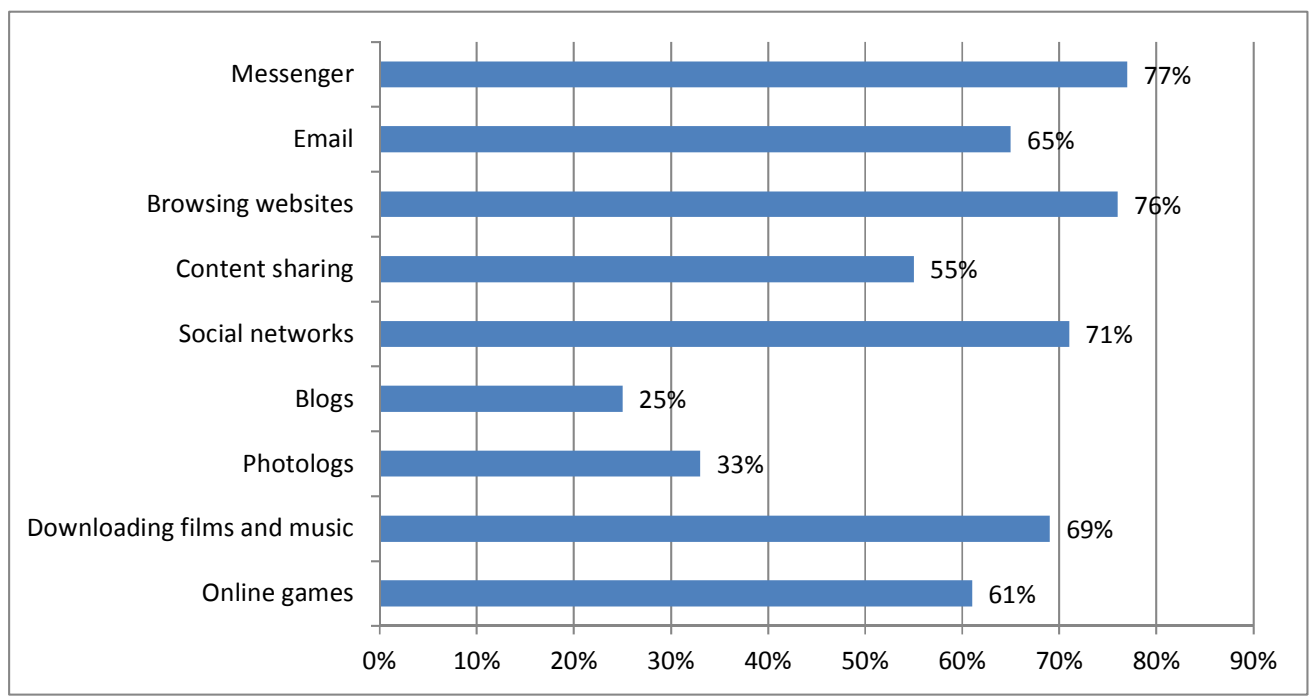

Rheingold (2002) argues that as a result of using SNSs, adolescents obtain social capital. Individuals deposit part of their knowledge and state of mind in the Web and, in return, receive knowledge and opportunities to socialize. For many reasons one could argue that the exchange of information, online chats and gossiping are the basic tools that mobilise youth's social capital (Rheingold, 2002; Valenzuela, Park, \& Kee, 2009). Gossiping or indulging in chitchat may seem unimportant activities, but they are essential to reaffirm relationships and show alliances or hierarchies (Tufekci, 2008). A quote from a teenager in Lleida describes quite accurately the role that SNSs such as Facebook have in everyday routine; it is particularly noteworthy the scale of priorities and how she balances time between homework and Facebook:

Girl, Lleida, Baccalaureate: When I arrive home I have lunch and after that I go to my computer to listen to music for a while and I also check Facebook. It depends on the amount of homework I have, but I am usually connected for half an hour or an hour. After that I do some homework but I connect intermittently to see what is going on. At night, if I am done with the homework, I connect and I stay logged in for a long time... 
Another teenager from the same Institute commented further:

Girl, Lleida, ESO: Well... I usually get home and have a little snack, then I go to my computer... and well, once I have checked Facebook and these things (probably referring to other SNSs) I start working on my homework...

When we asked our participants what they did while on Facebook, all of them agreed that they mainly spent time chatting and digging into friends' profiles just to know what were they doing. Thus, youngsters' digital activities are directly related to the social, cultural and psychological needs inherent in their developmental stage. As a consequence, their perception of how important the Internet is to them has less to do with the amount of time spent online and more with the quality of that time. Gossiping can be viewed as an effect of our disposition towards sociability (Patchin, \& Hinduja, 2010) which allows us to manage our position in relation with others (Denise, 2005). Also, the importance of online chats and "digital gossiping" lies in their ability to boost processes of empathy and atmospheres of trust. Sharing through SNSs creates secure spaces and trusted links that facilitate exchange. In general, social networks (both online and offline), provide secure spaces in which one can share experiences and this sharing process gives often rise to empathy or interpersonal intelligence, as revealed in the studies by Gardner (2004) and his theory of multiple intelligences.

\section{Adolescents' perception of the Internet and television}

Specific studies focusing on youth confirm adolescents' Internet affinity (Boyd, 2008; Denise, 2005; Ito, 2008, 2010; Valkenburg, \& Peter, 2011; Valkenburg, Sumter, \& Peter, 2011).

According to Spain's National Institute of Communications Technology (INTECO, 2008) 75.2\% of kids (aged between 10 and 16) prefer the Internet to other media because they believe it is either very entertaining (20.9\%) or somehow entertaining (54.3\%). Only $21.1 \%$ mention that they like it "a little" and a mere $1.6 \%$ declared that they liked it "not much or not at all." Regarding Catalonia, FUNDACC (Communication and Culture Audiences' Foundation) periodically publishes a survey containing data about young population's media preferences (1425 years old). In 2010, it consisted of $3 \mathrm{~h} 30 \mathrm{~m}$ television, $1 \mathrm{~h} 46 \mathrm{~m}$ Internet, $1 \mathrm{~h} 13 \mathrm{~m}$ radio, $13 \mathrm{~m}$ of newspapers and $4 \mathrm{~m}$ magazines a day. Compared to adults, youngsters spent 1 hour more on the Internet each day and 32 minutes less watching television (FUNDACC, 2010). What can be learned from this data?

Even though teenagers spend more minutes of their entertaining time watching TV than surfing the Web, television is not considered the main recreational and socialising tool. Regardless of the time spent on it, according to our focus groups the Internet is their preferred medium. In that sense, we asked our participants to rank, according to their preferences, the following activities: hanging out with friends, watching TV and surfing the Internet. In all eight focus groups, the responses obtained were the same: television is the least preferred activity, their first option is meeting with friends and, if not possible, surfing the Web:

Boy 1, Lleida, Baccalaureate: Well, I don't really know... You can be with your friends and on the Internet at the same time, if you have a cell phone... I have a cell and you know, TV is the least thing I would do. Because even if I don't have a television, I can still watch the same programs on my computer. And I can't hang out with my friends every single day! So if weekdays I cannot go out with them, I choose to be online...

The evening has become almost the only time when families gather together to watch TV, although this depends a lot on each family. Sometimes, sharing time in front of the TV set 
occurs because a family member says he or she follows a specific program. Other participants mentioned that they felt it was some sort of "family imposition," with parents and children watching TV together while they are having dinner.

Boy 1, Valls, Baccalaureate: I almost spend more time, quite a lot more, in front of the computer than in front of the TV.

Interviewer: You all agree that you spend more time on the Internet than in front of the TV?

All: Yes, yes.

Boy 2, Valls, Baccalaureate: You go to watch TV at very specific times, such as lunch time and dinner time... There is no place for TV in the middle of the afternoon. You are with your computer, you talk with your friends... the computer gives you more!

But this may not be just an adolescents' perception. Although television consumption rates are higher across all age groups, $61.6 \%$ of the Spanish population aged over 16 considers that the Internet is a "very important" source of information (figure 3), and $67.7 \%$ believes it is a "very important entertainment source" (figure 4).

Figure 3

Importance of media as an information source.

Source: World Internet Project (Spain) - Unpublished raw data $\mathrm{N}=2100$

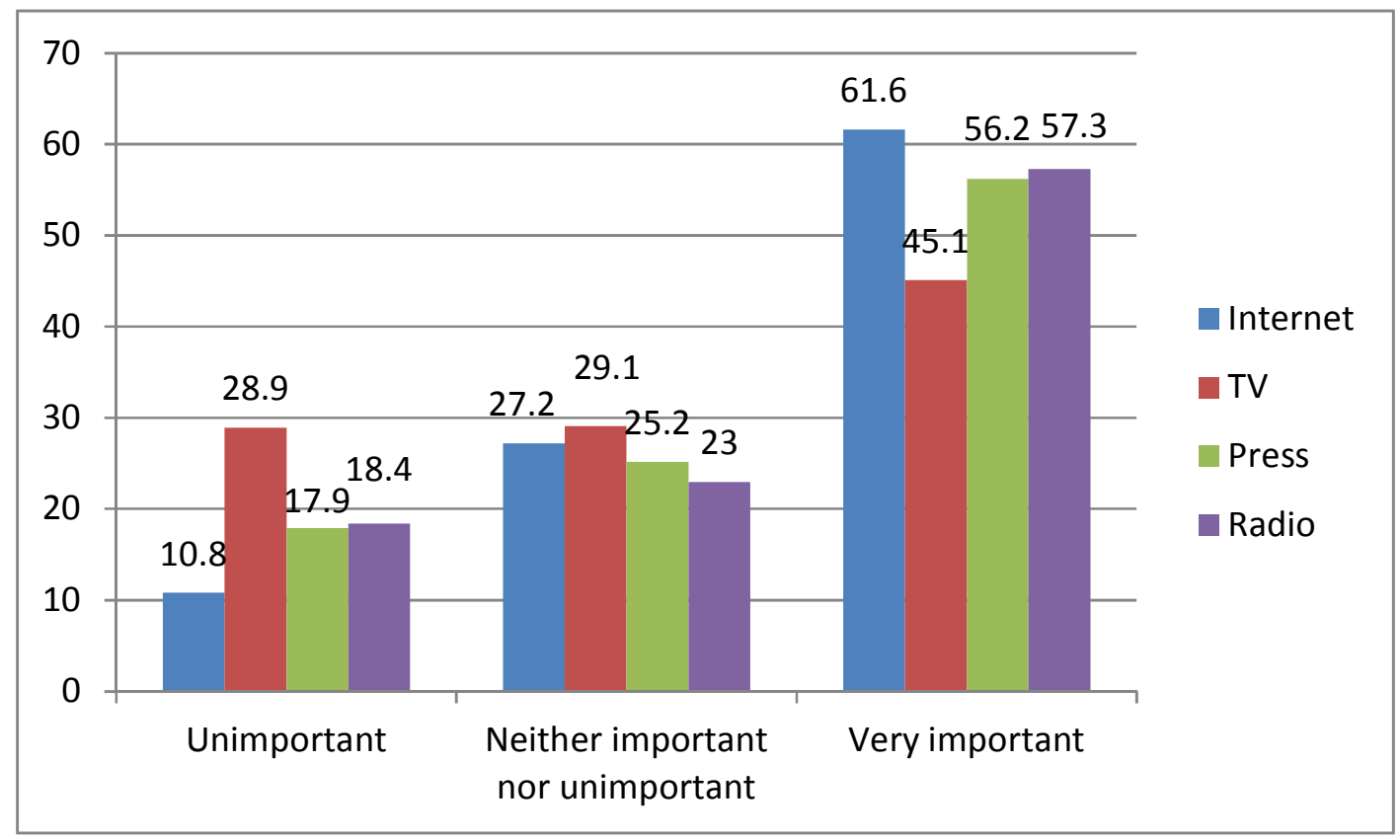


Figure 4

Importance of media as an entertainment source

Source: World Internet Project (Spain) - Unpublished raw data. N=2100

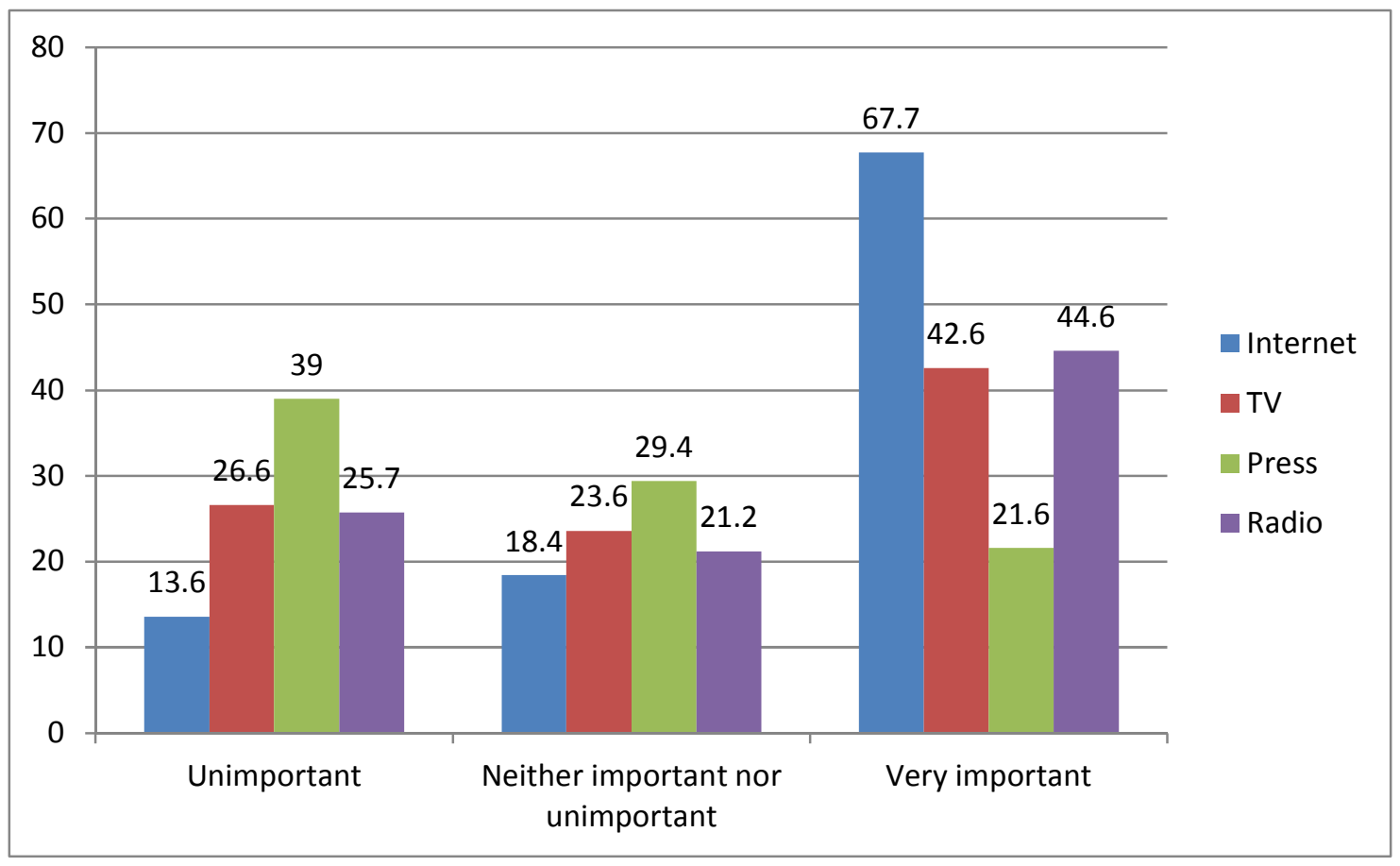

A plausible explanation for why the Internet is so meaningful to children and teenagers can be found in the fact that it plays a key role in their lives. It is not only about measuring time spent in front of a computer screen, but rather on how and why the Internet is used as a source of information and entertainment, together with the social context and the psychosocial needs of adolescents. We suggest that further in-depth qualitative research focused on the growing importance that the Internet has acquired for teenagers should be done. This research should relate aspects such as how, what and when they go online with the social, cultural and psychological characteristics of adolescence.

Identifying when families gathered together to spend some time watching a television program was another of our major research interests. We wanted to know if such practice was common and which were teenagers' thoughts on that matter. We asked our participants to share some thoughts on that matter and we discovered that while television consumption is associated with spaces related to family socialising and interaction (living room, kitchen...), adolescents relate activities like accessing the Internet to private spaces such as the bedroom; online activities tend to be considered "individual activities" or "bedroom activities" (Baker, 2004; Livingstone, 2007).

Boy, Lleida, Baccalaureate: Well, in my case, we all have dinner together and watch TV at the same time. Sometimes we watch the news, but sometimes it is just like background music... and we keep on talking and then, after dinner, I leave and my parents, depending on the day, watch TV together or...

Interviewer: Isn't there a program you all watch together?

Boy, Lleida, Baccalaureate: No, my parents maybe... But I won't, to an extent, watch TV with them during the week. 
The social and family-related nature of television consumption is clearly conditioned by the location of the TV sets. According to our respondents, the television is usually at the centre of home's main social spaces, such as the dining room, the living room and the kitchen. Thus, it is not surprising that time spent by parents watching television programs with their children mainly occurs after lunch or dinner and during the weekends (figure 5). This consumption usually takes place in the living room or in the kitchen (usually weekdays' lunches).

\section{Figure 5}

Time spent watching television with children (parents)

Source: data extracted from online survey sent to parents. $\mathrm{N}=257$

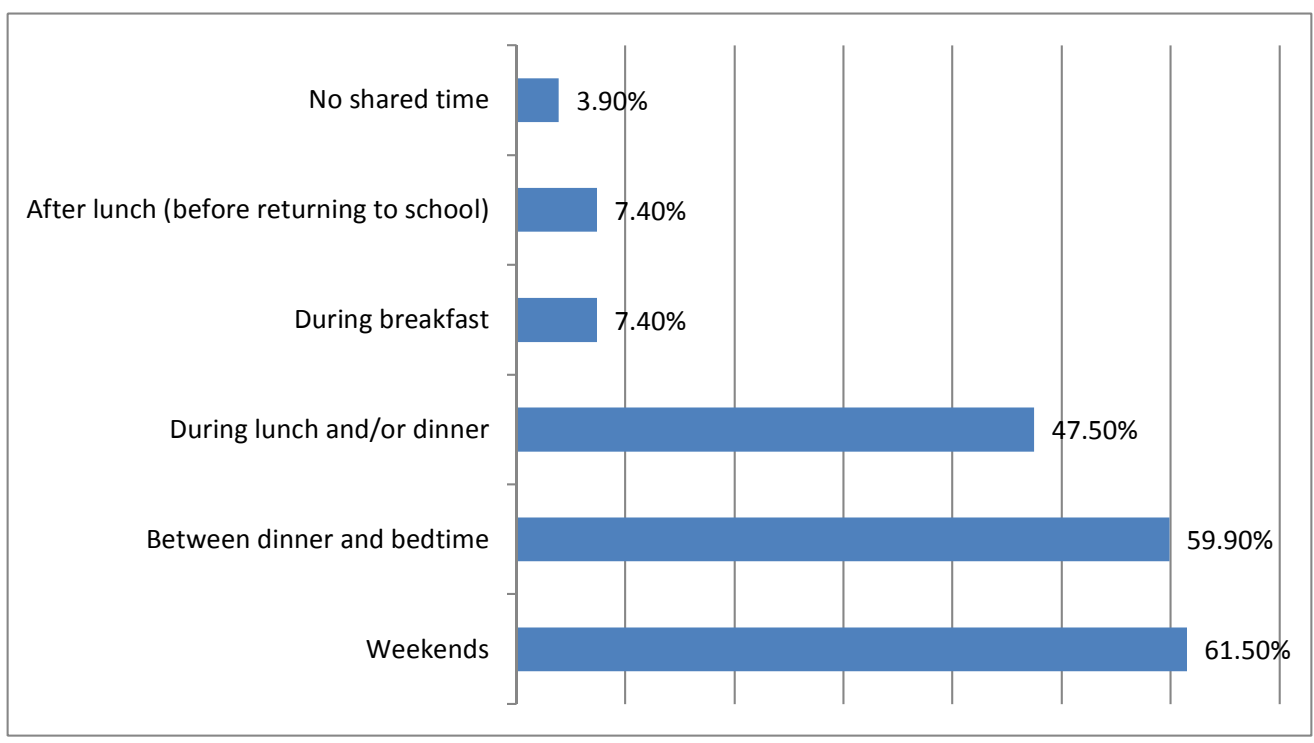

As it can be seen in the previous figure, families watch television together especially during weekends (61.5\%) and in the evening/night (59.9\%). It is also a common practice to watch it during mealtimes (47.5\%). But when the family is altogether in front of the TV... what are they watching? According to our participants (survey) they are watching films (70\%) and news $(65 \%)$, followed by entertainment shows (63\%) and sports (53\%). Content from the Internet is the least mentioned option, regardless of who (parent, son, daughter...) has downloaded it. 
Figure 6

TV programs watched together (parents and children) at the same place and time Source: data extracted from online survey sent to parents. $\mathrm{N}=257$

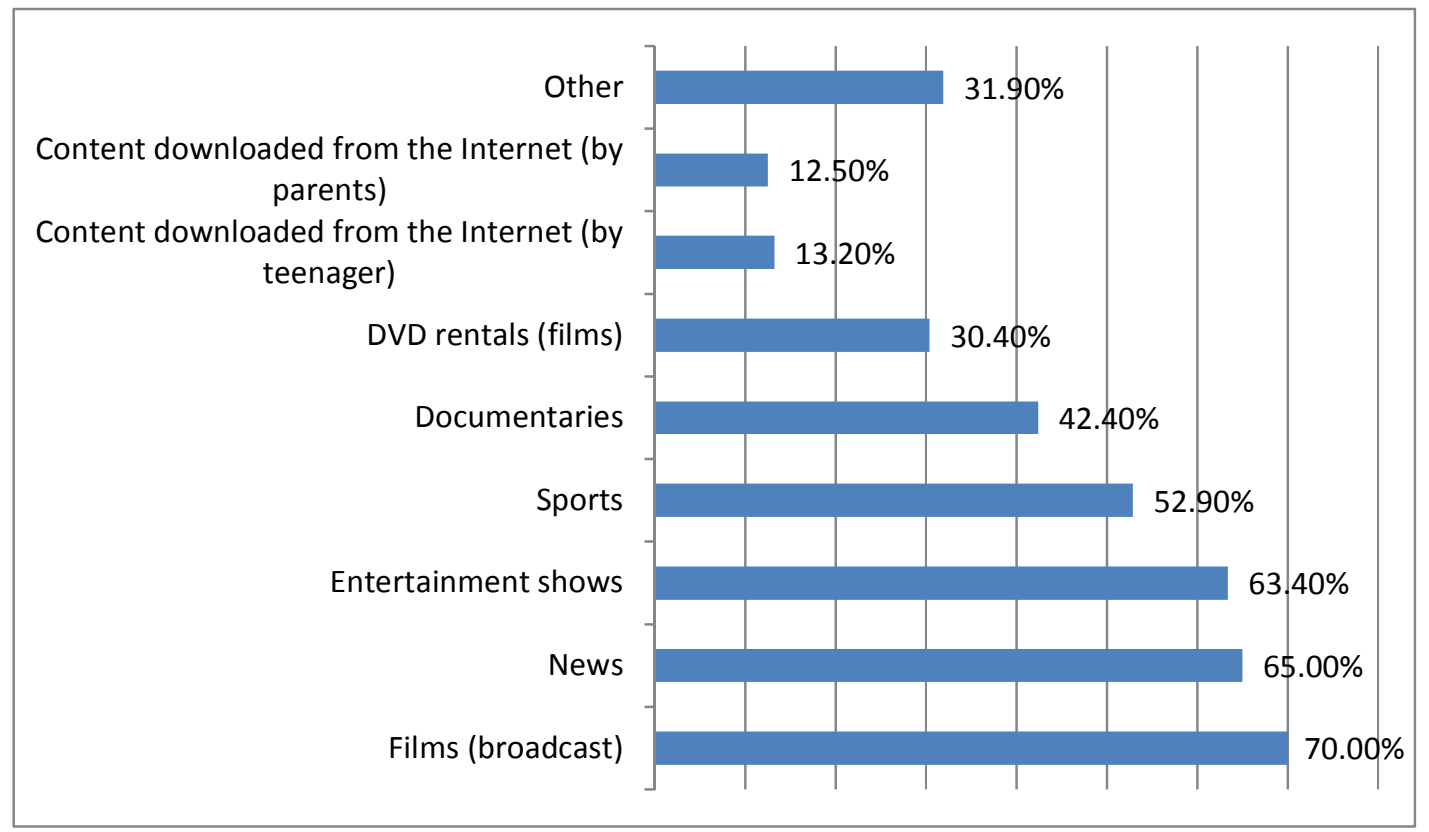

Computers, located in individual and private areas such as bedrooms and study rooms, offer personalised consumption in accordance with adolescents' needs and interests, which is why it is not common to find families that watch content together downloaded from the Internet. Accessing content that is available online may be a common practice for the youngsters but it is consumed in their private spaces (bedrooms) and on their own devices (mainly laptops). When parents and children sit in the couch, it is usually one of the parents who decide what to watch. The kid would just agree, knowing that once the show is over he/she will be free to go to the bedroom and make their own choices:

Girl 1, Tarragona, ESO: we try to reach an agreement, my brother, my sister and my parents... some days my parents decide, one day I decide... but usually we do not argue...

Boy 1, Tarragona, ESO: after dinner I usually stay with my parents half an hour watching something on TV and then I go to my bedroom, to my computer... after that I go to sleep.

Girl 1, Tarragona, ESO: I go to my room, I take the laptop to my bed and when it is late I turn it off...

Boy 2, Tarragona, ESO: sometimes I give the excuse that I'm tired and I say I go to sleep... and then I grab the computer...

In addition, watching television is socially and culturally determined by family dynamics, while the use of the Internet is mainly individual and private. However, we have also found some teenagers, usually ESO participants that make some appreciations regarding the idea that sharing a moment in front of the TV is something good because it is a "family bonding time:"

Interviewer: What type of program do you like to watch when you are with your parents, brothers and sisters? 
Boy 1, Girona, ESO: Quiz shows, movies, funny stuff (they mention some popular Spanish programs)

Girl 1, Girona, ESO: Yes! sometimes we watch funny programs... When my parents laugh, I like it, you know? (Girl 2: Me too!). I don't know, they're laughing and I'm happy!

Boy 2, Girona, ESO: they forget about their problems and other things...

Watching television means subrogating and compromising individual preferences and interests for the common or domestic good. Television content becomes the subject for family discussion and exchanges of values, opinions and shared recreational spaces. However, we have not found a single case in which participants in our focus groups mentioned that they usually argue or that they feel like their parents impose their choices.

\section{Discussion and Conclusions}

Although children and adolescents spend much more time watching television than on the Internet, TV is not regarded as their main recreational or entertainment tool. Regardless of the time spent, the Internet is their preferred medium and digital practices such as browsing SNSs (mainly Facebook) or listening to music online (usually via YouTube) are viewed by adolescents as a free activity that suits their social, cultural and psychological needs.

Watching television as a family activity is determined, socially and culturally, by family dynamics. On the contrary, the use of the Internet (individual and private) is socially and culturally determined by adolescents themselves, taking into consideration their private and recreational context, beyond family and/or adult influence.

Turning on the TV creates a common domestic context of discussion and entertainment (Morley, 1986). From this perspective, television is watched on the basis of family rules, interests and values. On the other hand, the Internet, consumed in private by the adolescents, is influenced by their own rules, values and interests and those of their social contexts, such as groups of friends, together with the psychosocial characteristics inherent in adolescence. All in all, Internet-related cultural and social consumption is viewed by adolescents as a more proper and fitted activity that suits their social, cultural and psychological needs, whilst television consumption is regarded as an activity linked to the home's communal spaces and to a schedule established by the broadcasters. Nonetheless, this does not have to imply, by any means, that television will play a secondary role in the cultural life of adolescents, but rather aims to explain their preference for the Internet.

Peers, parents and media provide values that have deep influence teenagers' development (habits, values...). Parental controls are a useful tool that have proven to work efficiently. However adolescents belong to a generation of digital natives and the Internet is part of their lives, so any attempt to block access to the Web is perceived as an attack to their independence. Internet is the platform where most of the adolescent media youth interests are gathered together: television programming, movies, photographs, friends, video games... Although television as a medium is still accepted, media consumption goes also inevitably through the Web so in the end, it is just a matter of figuring out how we merge traditional and upcoming consumption routines in a way that is satisfactory for all parties.

Acknowledgments: The authors wish to thank the Consell de l'Audiovisual de Catalunya (Catalan Broadcasting Council) for funding the research project Digital convergence and the young: the new spaces for audio-visual consumption (Resolution 113/2011 of 27 July 2011). 


\section{References}

Baker, S. (2004). Pop in(to) the bedroom: Popular music in pre-teen girls' bedroom culture, European Journal of Cultural Studies. 7(1), 75-93.

Boyd, D. (2008). Friendship. In: Ito, M. (Ed.) Hanging Out, Messing Around, Geeking Out: Living and Learning with New Media. (pp. 79-84) Cambridge, MA: MIT Press.

Boyd, D. (2007). Why Youth (Heart) Social Network Sites: The Role of Networked Publics in Teenage Social Life. Cambridge, MA: MIT Press.

Charmaz, K. (2005). Grounded theory in the $21^{\text {st }}$ Century. In N.K. Dezin \& Y.S. Lincoln (Eds.), The sage handbook of qualitative research (pp.507-535). Thousand Oaks, CA: Sage.

Cobo, C. (2010). The European and the International Framework of E-competencies. In M. Casalet (Ed.), El papel de las ciencias sociales en la construcción de la sociedad del conocimiento (pp.114-133 ). Flacso: México.

Creswell, J.W. (1998). Qualitative Inquiry and Research Design: Choosing Among Five Traditions. Thousand Oaks, CA.: Sage.

Denise, S. (2005). Presentation of Self on the Web: an Ethnographic study of teenage girls' Weblogs Education, Communication \& Information. 5(1), 25-39.

Fern, E.F. (2001). Advanced Focus Group Research. Thousand Oaks, CA: Sage.

FUNDACC. (2010). La dieta mediàtica i cultural del joves catalans. Retrieved from: www.fundacc.org

Gardner, H. (2004). Frames of Mind: The Theory of Multiple Intelligences. New York, NY: Basic Books.

Glaser, B., \& Strauss, A. (1967). The Discovery of Grounded Theory. Strategies for qualitative research. New York: Aldine Publishing.

INTECO. (2008). Study of secure habits in the use of ICT by children and adolescents and the e-confidence of their parents. Retrieved from:

http://www.inteco.es/indicators/Security/Observatory/Indicators/Indicador INT68

Ito, M. (Ed.). (2009). Hanging Out, Messing Around, and Geeking Out: Kids Living and Learning with New Media. Cambridge, MA: MIT Press.

Jenkins, H. (2008). Confronting the Challenges of Participatory Culture: Media Education for the $21^{\text {st }}$ Century. Chicago, IL: The MacArthur Foundation.

Lindlof, T.R., \& Taylor, B.C. (2002). Qualitative Communication Research Methods, 2nd Edition. Thousand Oaks, CA: Sage. 
Livingstone, S. (2007). From family television to bedroom culture: young people's media at home. In: Devereux, Eoin, (ed.) Media studies: key issues and debates. London: SAGE Publications.

Mediascope Europe. (2010). Pan-European Presentation Summary. Retrieved from: http://www.iabeurope.eu/media/53831/mediascope\%20europe\%202010\%20-\%20paneuropean $\% 20$ summary\%20slides.pdf

Morley, D. (1986). Family Television. Cultural power and domestic Leisure. London: Routledge.

Patchin, J., \& Hinduja, S. (2010). Trends in online social networking: adolescent use of MySpace over time. New Media \& Society. 12(2), 197-216.

Prensky, M. (2001). "Digital Natives, Digital Immigrants" On the Horizon. MCB University Press. 9(5), 1-6.

Rheingold, H. (2002). Smart mobs: the next social revolution. Cambridge, MA: Perseus Publishing

Sánchez, J., \& Aranda, D. (2013). "Messenger and social network sites as tools for sociability, leisure and informal learning for Spanish young people." European Journal of Communication, 28(1), 67-75.

Tapscott, D. (1998) Creciendo en un entorno digital. La Generación Internet. Santafé de Bogotá: McGraw-Hill.

Tufekci, Z. (2008). Can you see me now? Audience and disclosure regulation in online social network sites. Bulletin of Science, Technology \& Society, 28, 20-36.

Valenzuela, S., Park, N., \& Kee, K. (2009). Is There Social Capital in a Social Network Site?: Facebook Use and College Students' Life Satisfaction, Trust, and Participation. Journal of Computer-Mediated Communication, 14, 875-901.

Valkenburg, P.M., \& Peter, J. (2011). Adolescents' online communication: An integrated model of its attraction, opportunities, and risks. Journal of Adolescent Health, 48, 121-127.

Valkenburg, P.M., Sumter, S., \& Peter, J. (2011). Gender differences in online and offline selfdisclosure British Journal of Developmental Psychology, 29(2), 253-269.

\section{Additional References Intended for Readers Who Want to Learn More about the Topic}

Aranda, D., \& Sánchez-Navarro, J. (2011). Transformemos el ocio digital. Un proyecto de socialización en el tiempo libre. Barcelona: Fundación Catalana del Esplai.

Aranda, D., Sánchez-Navarro, J., \& Tabernero, C. (2009). Jóvenes y ocio digital. Informe sobre el uso de herramientas digitales por parte de adolescentes en España. Barcelona: Editorial UOC.

Castells, M., Tubella, I., Sancho, T., \& Roca, M. (2007) La transició a la societat xarxa. Barcelona: Ariel. 
Ito, M., Horst, H., Bittanti, M., Boyd, D., Herr-Stephenson, B., Lange, P.G., \& Robinson, L. (2008). Living and Learning with New Media: Summary of Findings from the Digital Youth Project. Retrieved from: http://digitalyouth.ischool.berkeley.edu/files/report/digitalyouthWhitePaper.pdf

Lin, N. (2001). Social Capital: A Theory of Social Structure and Action. Cambridge, MA: Cambridge University Press.

Livingstone, S., \& Haddon, L. (2009). Young People in the European Digital Media Landscape: A Statistical Overview. Göteborg, Sweden: International Clearinghouse on Children, Youth and Media.

Putnam, R. (2000). Bowling alone: the collapse and revival of American community. New York, NY: Simon and Schuster.

(C) Copyright of Journal of Youth Development Bridging Research and Practice. Content may not be copied or emailed to multiple sites or posted to a listserv without copyright holder's express written permission. Contact Editor at: patricia.dawson@oregonstate.edu for details. However, users may print, download or email articles for individual use. ISSN 2325-4009 (Print); ISSN 2325-4017 (Online) 